\title{
SULUH
}

JURNAL BIMBINGAN DAN KONSELING

http://journal.umpalangkaraya.ac.id/index.php/suluh Volume 5 Nomor 1, September 2019 (18-24)

\section{UPAYA MENINGKATKAN KETRAMPILAN GURU DALAM MENETAPKAN NILAI KIKIM MELALUI WORKSHOP DI SDN-5 MENDAWAI}

Efforts To Improve Teacher Skills In Setting KKIM Values Through Workshop In SDN-5 Mendawai

Muhammad Rusli

SDN 5 Mendawai, Kotawaringin Barat, Kalimantan Tengah, Indonesia

ARTIKEL INFO

Diterima

Dipublikasi

September 2019

\section{ABSTRAK}

Tujuan penelitian tindakan sekolah yang di lakukan pada guru di SDN-5 Mendawai adalah untuk meningkatkan meningkatkan ketrampilan guru dalam menetapkan nilai KKM melalui Workshop. Penelitian ini merupakan penelitian tindakan sekolah (School Action Research), karena penelitian dilakukan untuk memecahkan masalah proses pembelajaran di sekolah. Hasil observasi ada peningkatan skor rata-rata dari pra siklus ke siklus I, dimana hasil skor rata-rata observasi pra siklus hanya mencapai skor 5 sementara pada siklus I mencapai 9,3 yang artinya ketrampilan guru dalam menetapkan nilai KKM baik. Selanjutnya pada siklus II hasil observasi mencapai skor II,2 artinya Ketrampilan guru dalam menetapkan nilai KKM sangat baik.

Kata kunci: Keterampilan Guru, Penetapan Nilai KKM, Workshop

\section{ABSTRACT}

The aim of the school action research conducted on teachers at Mendawai SDN-5 is to improve the improvement of teacher skills in determining KKM grades through the Workshop. This research is a school action research (School Action Research), because the research was conducted to solve the problem of the learning process at school. The results of observations there is an increase in the average score from pre-cycle to the first cycle, where the results of the average score of the pre-cycle observation only reached a score of 5 while in the first cycle it reached 9.3 which means the teacher's skills in determining the KKM score is good. Furthermore, in the second cycle the observation results reached a score of II.2 meaning that the teacher's skills in determining KKM scores are very good.

Keywords: Teacher Skills, KKM Value Determination, Workshop

*e-mail :

Orcid :

(C) Universitas Muhammadiyah Palangkaraya 
Jurnal Bimbingan dan Konseling

\section{PENDAHULUAN}

Kebijakan pemerintah di bidang pendidikan telah bergulir dengan ditetapkannya Peraturan Pemerintah Nomor 19 Tahun 2005 tentang Standar Nasional Pendidikan (SNP) yang meliputi standar isi, standar proses, standar kompetensi lulusan, standar pendidik dan tenaga kependidikan, standar sarana prasarana, standar pengelolaan, standar pembiayaan, dan standar penilaian pendidikan.

UU No. 20 tahun 2003 tentang sistem Pendidikan Nasional dan PP No. 19 tahun 2005 tentang Standar Nasional Pendidikan (SNP) mengamanatkan bahwa kurikulum pada jenjang Pendidikan Dasar dan Menengah dikembangkan oleh setiap satuan pendidikan. Pemerintah tidak lagi menetapkan kurikulum secara nasional seperti pada periode sebelumnya. Satuan pendidikan harus mengembangkan sendiri kurikulum sesuai dengan karakteristik dan kebutuhan serta potensi peserta didik, masyarakat, dan lingkungannya.

Penetapan Kriteria Ketuntasan Minimal (KKM) merupakan tahapan awal pelaksanaan penilaian hasil belajar sebagai bagian dari langkah pengembangan Kurikulum 2013. Kurikulum ini menggunakan acuan kriteria dalam penilaian, mengharuskan pendidik dan satuan pendidikan menetapkan KKM dengan analisis dan memperhatikan mekanisme dan prosedur penentuan KKM.

Oleh karena itu, perlu diberikan informasi pada awal tahun pelajaran melalui kolektif guru, workshop sehingga dapat dijadikan pedoman dalam penetapan KKM. Workshop disebut juga dengan lokakarya atau pelatihan. Tempat workshop inilah yang dijadikan sebagai tempat menjajakan banyak ilmu yang diterapkan dalam penyajian materi beserta dengan praktiknya. Sama dengan seminar, ada materi yang diujikan pembahasan dalam workshop ini. Semuanya materi dikupas tuntas dan disertai dengan pelatihan. Peserta yang telah mengikuti workshop ini pasti memiliki produk atau hasil karya.

Beberapa keterampilan yang berguna yang diperlukan oleh para guru abad 21 . Kesabaran ada di bagian atas daftar. Kemudian kita berbicara tentang kemampuan untuk beradaptasi dengan teknologi baru dan bagaimana mengelola reputasi online kami $\mathrm{di}$ media sosial, bersama dengan 8 keterampilan lain yang kami butuhkan untuk guru saat ini adalah kesabaran dan kegigihan, memahami perkembangan teknologi, berperan sebagai tim dan memanajemen "reputasi online" seorang guru.

Dalam menetapkan nilai KKM, kita bisa menggunakan berbagai macam cara. Diantaranya adalah dengan menggunakan nilai kriteria yang dikonversi ke dalam sebuah nilai tertentu.

Ada 3 cara untuk mengkonversi atau menafsirkan Kriteria menjadi sebuah nilai, diantaranya:

I. Dengan memberikan point pada setiap 
Jurnal Bimbingan dan Konseling

kriteria yang ditetapkan :

Kompleksitas:

Tinggi $=1$

Sedang $=2$

Rendah $=3$

Daya dukung:

Tinggi $=3$

Sedang $=2$

Rendah $=$ I

Dengan keterangan sebagai berikut:

jika indikator memiliki Kriteria :

kompleksitas rendah, daya Dukung tinggi dan intake siswa sedang nilainya adalah:

$(3+3+2) \times 100=88.89$

2. Dengan menggunakan rentang nilai pada setiap kriteria:

Kompleksitas:

Tinggi $=50-64$

Sedang $=65-80$

Rendah $=8 \mathrm{I}-100$

Daya dukung:

Tinggi $=8 \mathrm{I}-100$

Sedang $=65-80$

Rendah $=50-64$

Keterangan berikut ini:

Jika indikator memiliki Kriteria : kompleksitas sedang, daya dukung tinggi dan intake sedang, nilainya adalah rata-rata setiap nilai dari kriteria yang kita tentukan.

Catatan: Dalam menentukan rentang nilai dan menentukan nilai dari setiap kriteria perlu kesepakatan dalam forum MGMP di
Sekolah

3. Dengan memberikan pertimbangan professional judgment pada setiap kriteria untuk menetapkan nilai :

Kompleksitas:

Tinggi

Sedang

Rendah

Daya dukung:

Tinggi

Sedang

Rendah

Keterangan:

Jika indikator memiliki Kriteria : kompleksitas rendah, daya Dukung tinggi dan intake siswa sedang maka dapat dikatakan hanya satu komponen yang mempengaruhi untuk mencapai ketuntasan maksimal 100 yaitu intake sedang. Jadi guru dapat mengurangi nilai menjadi antara $90-80$.

Workshop berasal dari Bahasa Inggris, terdiri dari dua kata "work" yang artinya bekerja atau berkegiatan dan "shop" yang berarti toko atau tepat untuk menjajakan dagangan. Keduanya kemudian dikirim sebuah kata yang bernama "workshop".

Workshop disebut juga dengan lokakarya atau pelatihan. Tempat workshop inilah yang dijadikan sebagai tempat menjajakan banyak ilmu yang diterapkan dalam penyajian materi beserta dengan praktiknya.

Berdasarkan pengertian workshop, 
Jurnal Bimbingan dan Konseling

maka fungsi workshop adalah untuk mendokumentasikan hasil pengamatan memberikan pelatihan kepada peserta terkait tersebut.

dengan bidang profesinya. Misalnya adalah untuk guru, maka dijadikan sebagai bekal dalam mengembangkan inovasi pembelajaran.

\section{METODOLOGI PENELITIAN}

Penelitian ini merupakan penelitian tindakan sekolah (School Action Research), karena penelitian dilakukan untuk memecahkan masalah proses pembelajaran di sekolah. Penelitian ini menggambarkan bagaimana suatu teknik pembelajaran diterapkan dan bagaimana hasil yang diinginkan dapat dicapai. Penelitian ini mengambil bentuk penelitian tindakan sekolah (PTS) yaitu peningkatan ketrampilan guru dalam menetapkan nilai KKM melalui kunjungan kelas dalam rangka mengimplementasikan standar proses, yang terdiri dari 3 siklus dan masing- masing siklus terdiri dari 4 tahap yaitu tahap perencanaan program tindakan, pelaksanaan program tindakan, pengamatan program dan refleksi.

Agar pelaksanaan penerapan Workshop untuk meningkatkan ketrampilan guru dalam menetapkan nilai KKM yang dilakukan dapat berjalan dengan baik, Kepala Sekolah mengadakan pengamatan langsung terhadap aktivitas semua guru, disamping itu juga guru diminta mengisi daftar kehadiran yang diisi setiap hari untuk mengetahui jam keberangkatan dan kepulangan dari semua guru di SDN-5 Mendawai. Kemudian

\section{HASIL DAN PEMBAHASAN}

Pada pra siklus peneliti baru mengamati seberapa besar Ketrampilan guru dalam menetapkan nilai KKM dan ternyata hasilnya sangat rendah yakni mendapat skor rata-rata Cuma 5 artinya Ketrampilan guru dalam menetapkan nilai KKM kurang baik

Lalu di lanjutkan siklus I peneliti (kepala sekolah) sudah mengadakan Workshop untuk memperbaiki ketrampilan guru dalam menetapkan nilai KKM di SDN-5 Mendawai.

Acara dalam kegiatan Workshop tersebut adalah

I. Pembukaan

2. Ucapan selamat datang dari kepala sekolah

3. Sambutan dari kepala UPT

4. Materi, berikut adalah materi Workshop:

a. Menjumlahkan Kompetensi Dasar (KD) setiap mata pelajaran setiap kelas.

b. Menentukan kekuatan / nilai untuk setiap aspek / komponen sesuai dengan kemampuan masing-masing aspek.

c. Menetapkan KKM tiap KD

d. Menghitung KKM mata pelajaran

e. Doa penutup

Di lihat dari hasil observasi ada peningkatan skor rata-rata dari pra siklus ke 
Jurnal Bimbingan dan Konseling

siklus I, dimana hasil skor rata-rata observasi pra siklus hanya mencapai skor 5 sementara pada siklus I mencapai 9,3 yang artinya ketrampilan guru dalam menetapkan nilai KKM baik.

Selanjutnya pada siklus II hasil observasi mencapai skor II,2 artinya Ketrampilan guru dalam menetapkan nilai KKM sangat baik.

Workshop dalam menetapkan kriteria ketuntasan minimal di SDN-5 Mendawai dapat dilakukan melalui pengamatan dan pemantauan kepala sekolah dalam kegiatan Workshop. Dari hasil analisis diperoleh hasil bahwa, Workshop sangat efektif untuk meningkatakan Ketrampilan guru dalam menetapkan nilai KKM, karena guru memiliki kesempatan mendiskusikan secara bersamasama untuk mengkaji dan memecahkan permasalahan berdasarkan keadaan di lapangan, kemudian dapat memperbaikinya atau melakukan tindak lanjut pada siklus berikutnya secara terus menerus apabila masalah belum terselesaikan.

\section{KESIMPULAN}

Pada pra siklus peneliti baru mengamati seberapa besar Ketrampilan guru dalam menetapkan nilai KKM dan ternyata hasilnya sangat rendah yakni mendapat skor rata-rata Cuma 5 artinya Ketrampilan guru dalam menetapkan nilai KKM kurang baik

Lalu di lanjutkan siklus I peneliti (kepala sekolah) sudah mengadakan Workshop untuk memperbaiki ketrampilan guru dalam menetapkan nilai KKM di SDN-5 Mendawai.

Acara dalam kegiatan Workshop tersebut adalah

I. Pembukaan

2. Ucapan selamat datang dari kepala sekolah

3. Sambutan dari kepala UPT

4. Materi, berikut adalah materi Workshop:

a. Menjumlahkan Kompetensi Dasar (KD) setiap mata pelajaran setiap kelas.

b. Menentukan kekuatan / nilai untuk setiap aspek / komponen sesuai dengan kemampuan masing-masing aspek.

c. Menetapkan KKM tiap KD

d. Menghitung KKM mata pelajaran

e. Doa penutup

Di lihat dari hasil observasi ada peningkatan skor rata-rata dari pra siklus ke siklus I, dimana hasil skor rata-rata observasi pra siklus hanya mencapai skor 5 sementara pada siklus I mencapai 9,3 yang artinya ketrampilan guru dalam menetapkan nilai KKM baik.

Selanjutnya pada siklus II hasil observasi mencapai skor II,2 artinya Ketrampilan guru dalam menetapkan nilai KKM sangat baik.

Workshop dalam menetapkan kriteria ketuntasan minimal di SDN-5 Mendawai dapat dilakukan melalui pengamatan dan pemantauan kepala sekolah dalam kegiatan Workshop. Dari hasil analisis diperoleh hasil 
Jurnal Bimbingan dan Konseling

bahwa, Workshop sangat efektif untuk meningkatakan Ketrampilan guru dalam menetapkan nilai KKM, karena guru memiliki kesempatan mendiskusikan secara bersamasama untuk mengkaji dan memecahkan permasalahan berdasarkan keadaan di lapangan, kemudian dapat memperbaikinya atau melakukan tindak lanjut pada siklus berikutnya secara terus menerus apabila masalah belum terselesaikan.

Berdasarkan penelitian yang telah dilakukan maka peneliti membuat saransaran berikut:

I. Untuk Guru. Dengan meningkatkan ketrampilannya dalam menentukan nilai KKM sudah tentu akan membawa dampak positif baik bagi diri guru sendiri dan juga bagi para siswa.

2. Untuk Para Kepala Sekolah. Bagi para kepala sekolah teruslah mencari dan menerapkan program-program yang pas dan cocok untuk memperbaiki kualitas pengajar di sekolah. Hal ini akan menunjang sekali pada tercapainya tujuan pembelajaran.

3. Bagi kalangan umum. Bagi kalangan umum bisa membaca dan menjadikan refrensi hasil tulisan saya ini untuk memilih metode dalam meningkatkan Ketrampilan guru dalam menetapkan nilai KKM.

\section{DAFTAR PUSTAKA}

Arikunto Suharsimi. 1992. Prosedur Penelitian. Jakarta: PT. Rineka Cipta.

Badudu - Zain. 1994. Kamus Umum Bahasa
Indonesia. Jakarta: Pustaka Sinar Harapan.

Boediono. 1998. Pembinaan Profesi Guru dan Psikologi Pembinaan Personalia. Jakarta ; Departemen Pendidikan dan Kebudayaan.

Imam Gunawan. 20/3. Metode Penelitian Kualitatif Teori dan Praktik. Jakarta: PT Bumi Aksara.

Peraturan Menteri Pendidikan Nasional Republik Indonesia Nomor 20 Tahun 2007 tentang Standar Penilaian Pendidikan. Jakarta: Direktorat

Peraturan Menteri Pendidikan Nasional Republik Indonesia Nomor 22 Tahun 2006, tentang Standar Isi. Jakarta. 2006. Peraturan Pemerintah Nomor 19 Tahun 2005 tentang Standar Nasional Pendidikan. Jakarta:Fokus Media.

Sudibyo, Bambang. 2008.Model dan Teknik Penilaian pada Tingkat Satuan Pendidikan Dasar dan Menengah. Jakarta: Departemen Pendidikan Nasional.

Sudjana, Nana. 2012. Penilaian Hasil Proses Belajar Mengajar. Bandung: PT Remaja RoSDakarya.

Sugiyono. 2007. Metode Penelitian Kuantitatif Kualitatif dan R \& D. Bandung: Alfabeta CV.

Suharjono. 2010. Penelitian Tindakan Kelas dan Penelitian Tindakan Sekolah. Malang: Lembaga Cakrawala Indonesia (LCl). 


\section{Jurnal Bimbingan dan Konseling}

Undang-Undang Nomor 20 Tahun 2003

tentang Sistem Pendidikan Nasional.

Jakarta: Fokus Media. 